\title{
Physical Fitness And Performance of Polish Ice-Hockey Players Competing at Different Sports Levels
}

\author{
by \\ Robert Roczniok ${ }^{1}$, Arkadiusz Stanula1, Tomasz Gabryś2, Urszula Szmatlan-Gabryśs, \\ Artur Gołaś ${ }^{1}$, Petr Stastny ${ }^{4}$
}

\begin{abstract}
The study aimed to determine the values of selected aerobic and anaerobic capacity variables, physical profiles, and to analyze the results of on-ice tests performed by ice-hockey players relegated to a lower league. Performance of 24 ice-hockey players competing in the top league in the 2012/2013 season was analysed to this end. In the 2013/2014 season, 14 of them still played in the top league (the control group), while 10 played in the first league (the experimental group). The study was conducted one week after the end of the playoffs in the seasons under consideration. The results revealed that only in the experimental group the analysed variables changed significantly between the seasons. In the Wingate test, significant changes were only noted in mean relative power (a decrease from 9.91 to $9.14 \mathrm{~W} / \mathrm{kg} ; p=0.045$ ) and relative total work (a decrease from 299.17 to $277.22 \mathrm{~J} / \mathrm{kg} ; \mathrm{p}=0.048$ ). The ramp test indicated significantly lower power output in its final stages (364 compared with $384 \mathrm{~W} ; p=0.034$ ), as well as a significant decrease in relative VO2max (from 52.70 to $48.30 \mathrm{ml} / \mathrm{min} / \mathrm{kg}$ ). Blood lactate concentrations were recorded at the $3 \mathrm{rd}, 6 \mathrm{th}$, 9th and $12 \mathrm{th}$ min of recovery after the ramp test. The rate of post-exercise recovery, $\triangle L A$, recorded after the ramp test turned out to be significantly lower. The times recorded in the on-ice "6x30 m stop" test increased from 32.18 to $33.10 \mathrm{~s}$ ( $p=0.047)$. The study showed that playing in a lower league where games were less intensive, training sessions shorter and less frequent, had an adverse effect on the performance level of the investigated players. Lower VO2max recorded in the study participants slowed down their rates of post-exercise recovery and led to a significantly worse performance in the $6 \times 30 \mathrm{~m}$ stop test, as well as lower relative power and relative total work in the Wingate test.
\end{abstract}

Key words: team sports, recovery, on-ice tests, aerobic capacity, anaerobic capacity.

\section{Introduction}

Ice-hockey is considered one of the most demanding and fastest team sport games. As the intensity of play has been observed to increase in recent years, the focus of training of ice-hockey players at the highest competitive level focused on muscle strength, aerobic capacity, anaerobic power, speed and agility (Bem et al., 2005; Montgomery, 2006; Quinney et al., 2008; Roczniok et al., 2013; Stanula et al., 2013). Ice hockey is a physically demanding contact sport involving repeated bouts of high energy output lasting from 30 to 80 s (Green et al., 2004; Lau et al., 2001; Montgomery, 1988). Professional ice-hockey games are characterized by intense bouts of play lasting from 45 to $60 \mathrm{~s}$, rarely exceeding $90 \mathrm{~s}$ (Cox et al., 1995). Ice-hockey requires that the players have finely trained aerobic and anaerobic energy pathways. To play ice-hockey at the top level,

\footnotetext{
1 - Department of Sports Training, The Jerzy Kukuczka Academy of Physical Education, Katowice, Poland.

2 - Department of Physical Education, State School of Higher Education, Oświęcim, Poland.

3 - Department of Physiotherapy, Section of Anatomy, The University School of Physical Education, Cracow, Poland.

4 - Palacky University in Olomouc, Faculty of Physical Culture, Olomouc, Czech Republic.
} 
intense glycolytic activity related to the bursts of intense muscular activity $(69 \%$ anaerobic glycolysis) and exceptional aerobic power and endurance (31\% aerobic metabolism) are required (Cox et al., 1995; Montgomery, 1988; Magiera et al., 2013). Moreover, when the intensity of an icehockey game is high, the actual engagement of the player's anaerobic systems may depend on the efficiency of his aerobic system. Aerobic processes play an important role in the resynthesis of energy substrates, which are necessary to exercise at high intensity (Roczniok et al., 2016; Stanula et al., 2014). Cox et al. (1995) analyzed detraining effects on the physiological profile of ice-hockey players during a competitive season. In this line, the present study was undertaken with the purpose of establishing if the relegation to a lower league resulted in lower values of selected aerobic and anaerobic capacity variables, influenced physical profiles and the results of on-ice tests in ice-hockey players.

\section{Material and Methods}

\section{Participants}

The experiment involved 24 ice-hockey players competing in the top league in the $2012 / 2013$ season. In the 2013/2014 season, 14 of them still played in the top league (the control group), while 10 played in the first league (the experimental group). The research was conducted one week after the end of the playoffs in the seasons under consideration (April 2013, 2014). All the athletes possessed up-to-date medical examinations confirming proper health status and the ability to perform high-intensity exercise. The research project was approved by the Ethics Committee for Scientific Research at the Jerzy Kukuczka Academy of Physical Education in Katowice.

\section{Research design}

Data collection was conducted in April 2013 and April 2014. Tests lasted three days for each ice hockey player. On the first day, body measurements were made. Body height was determined including barefoot height $( \pm 0.1 \mathrm{~cm})$ using a wall mounted stadiometer. Body composition was estimated using an 8-electrode bioimpedance analysis device (InBody 720, Biospace). All the measurements were taken by a certified representative of MEDfitness, a sole distributor of the InBody body composition ana lyzer in Poland. Body mass and composition measurements were taken in the morning (09.00$10.00 \mathrm{am})$, two hours after a light breakfast. The participants did not exercise or take any medication prior to the measurements, which were performed at a temperature of $21^{\circ}$. The ICC for the body composition analysis varied from 0.84 to 0.97 . Three hours after breakfast, each athlete performed the $30 \mathrm{~s}$ Wingate test to determine anaerobic capacity. The test and a 5 min warm-up were performed on an electromagnetically braked cycloergometer (Excalibur Sport, Lode). Resistance during the warm up was set at $1 \mathrm{~W}$ per $1 \mathrm{~kg}$ of body mass and pedal frequency of approximately 70 RPM. The Wingate test was performed with resistance adjusted to athlete's body mass $\left(0.08 \mathrm{Nm} \cdot \mathrm{kg}^{-1}\right)$. Capillary blood samples were drawn at rest and after the 4 th and 8 th min of the test to determine lactate concentration. All of the ice hockey players were instructed to cycle as quickly and forcefully as possible throughout the $30 \mathrm{~s}$ test.

After $48 \mathrm{~h}$ of rest, all subjects performed a ramp ergocycle test (T30x1) (30 W· $\left.\mathrm{min}^{-1}\right)$ with a progressive workload $\left(0.5 \mathrm{~W} \cdot \mathrm{s}^{-1}\right)$ until volitional exhaustion, to establish maximal oxygen uptake $\left(\mathrm{VO}_{2 \max }\right)$ and determine the anaerobic threshold. Each ramp test was started with the resistance set at $30 \mathrm{~W}$ and pedal frequency between 70 to 80 rpm. In this phase, capillary blood samples were drawn to determine lactate concentration before and immediately after the end of the $\mathrm{T} 30 \times 1$ as well as at the 3rd, 6th, 9th and 12th min of recovery. During the T30 $\times 1$ protocol, the following variables were constantly registered: a heart rate $(\mathrm{HR})$, minute ventilation (VE), oxygen uptake $\left(\mathrm{VO}_{2}\right)$ and expired carbon dioxide $\left(\mathrm{CO}_{2}\right)$, a respiratory exchange ratio (RER), breath frequency (BF) (MetaLyzer 3B-2R, Cortex). Maximal oxygen uptake $\left(\mathrm{VO}_{2 \max }\right)$ was assessed when the following criteria were met: (1) reaching a plateau in $\mathrm{VO}_{2}$ with increases in the work load $\left(\Delta \mathrm{VO}_{2} \leq 100 \mathrm{~mL} \cdot \mathrm{min}^{-1}\right.$ at $\mathrm{VO}_{2}$ peak); (2) maximal respiratory exchange ratio RER $\geq 1.1$. All breath-bybreath gas exchange data were time-averaged using $15 \mathrm{~s}$ intervals to examine the oxygen plateau. All the ramp tests were performed on an ergocycle Excalibur Sport (Lode). Seat and bar height of the cycle ergometer were adjusted for each subject.

After $48 \mathrm{~h}$ of rest, during the last day of 
testing involving an on-ice test, subjects wore full hockey equipment except for the stick. Specific physical fitness tests on ice were carried out in order to provide information about the speed and endurance of the athlete: $30 \mathrm{~m}$ Sprint Forwards, 30 $\mathrm{m}$ Sprint Backwards, $6 \times 9 \mathrm{~m}$ Stops, $6 \times 9 \mathrm{~m}$ Turns, Endurance $(6 \times 30 \mathrm{~m})$. Microgate Photocells (Bolzano, Italy) recorded the times of each sprint with accuracy of $0.01 \mathrm{~s}$.

\section{Statistical analysis}

All statistical analyses were conducted using Statistica 12.0. Basic descriptive statistics were calculated. The Wilcoxon's matched pairs test for dependent variables was used to evaluate the mean differences. Statistical significance was set at $p<0.05$.

\section{Results}

The analysis of research results started with the presentation and comparison of basic descriptive statistics of somatic variables.

No significant differences in the mean values of the variables were found, what indicated that playing in the lower league did not have a significant effect on somatic variables in the selected ice-hockey players. In the next step, the results of the $30 \mathrm{~s}$ Wingate test were analysed (Table 2).
Statistically significant differences were found only between the results in the experimental group for variables Relative mean power and Relative total work. Ice hockey players from the experimental group in the 2013/2014 season had lower values of relative mean power (9.14) compared to the results of the 2012/2013 season $\left(9.91 \mathrm{~W} \cdot \mathrm{kg}^{-1} ; p=0.04\right)$ which they played at the top league. Analysis of the results of relative total work also indicated a statistically significant decrease in relative total work after a year spent in the lower league ( $p=0.04$; Table 2). Further analysis related to aerobic capacity is presented in Table 3.

Relative $\mathrm{VO}_{2 \max }(\mathrm{ml} / \mathrm{min} / \mathrm{kg})$ - relative maximal oxygen uptake. LA rest $\left(\mathrm{mmol} \cdot \mathrm{l}^{-1}\right)$ lactate concentration before the $\mathrm{VO}_{2 \max }$ test. LA $\mathrm{L}_{\max }$ $\left(\mathrm{mmol} \cdot \mathrm{1}^{-1}\right)$ - lactate concentration after the $\mathrm{VO}_{2 \max }$ test. $\Delta$ LAmax-rest3' $\left(\mathrm{mmol} \cdot \mathrm{l}^{-1}\right)$ - difference between the maximum concentration of lactate and lactate concentration in the $3^{\text {rd }}$ min after the $\mathrm{VO}_{2 \max }$ test. $\Delta \mathrm{LA}_{\text {max-rest6' }}\left(\mathrm{mmol} \cdot \mathrm{1}^{-1}\right)$ - difference between the maximum concentration of lactate and lactate concentration in the $6^{\text {th }}$ min after the $\mathrm{VO}_{2 \max }$ test. $\Delta \mathrm{LA}_{\text {max-rest9' }}\left(\mathrm{mmol} \cdot \mathrm{1}^{-1}\right)$ - difference between the maximum concentration of lactate and lactate concentration in the $9^{\text {th }}$ min after the $\mathrm{VO}_{2 \max }$ test. $\Delta \mathrm{LA}_{\text {max-rest12' }}\left(\mathrm{mmol} \cdot \mathrm{l}^{-1}\right)$ - difference between the maximum concentration of lactate and lactate concentration in the $12^{\text {th }}$ min after the $\mathrm{VO}_{2 \max }$ test.

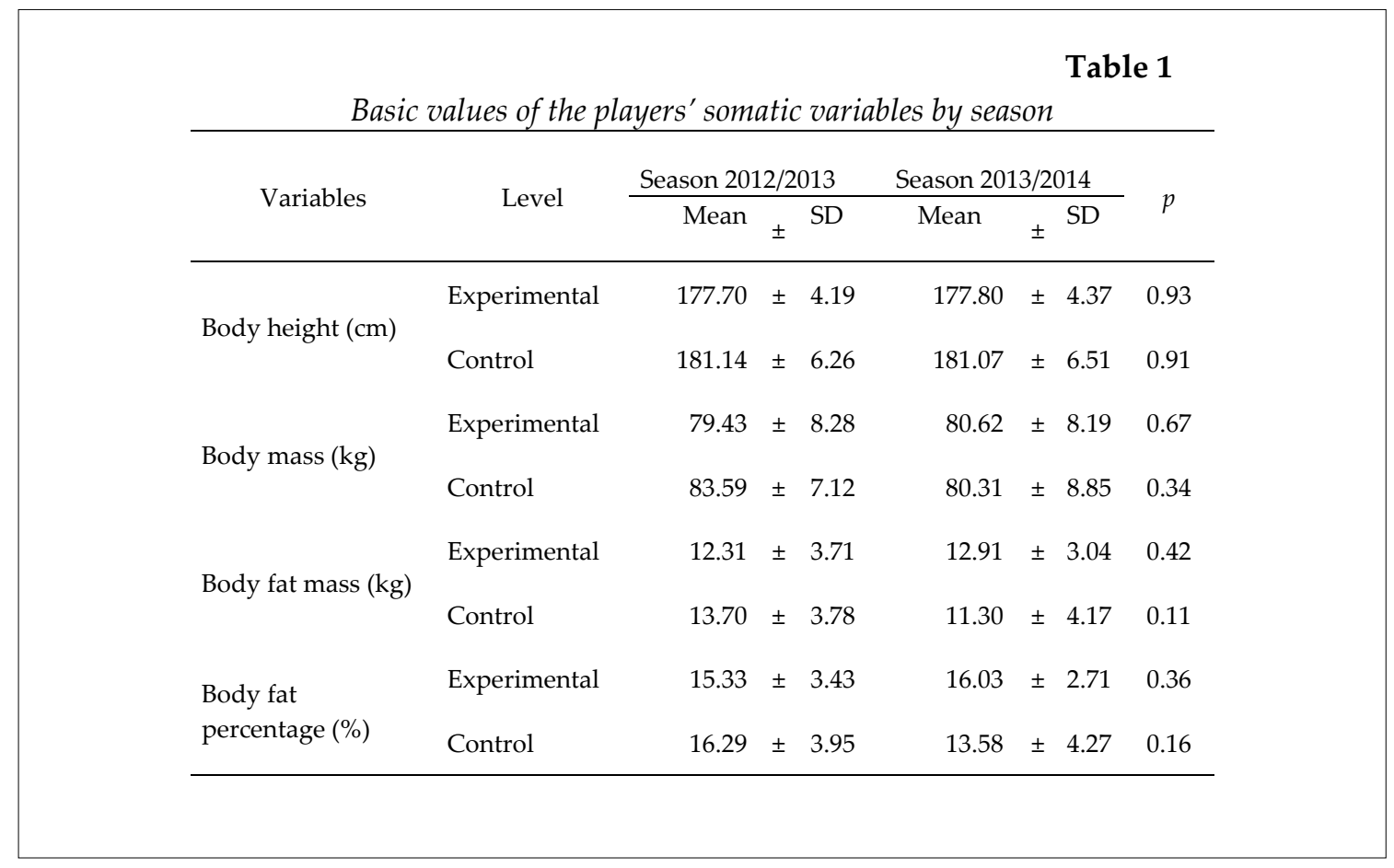


Table 2

Basic statistical characteristics of the players' anaerobic capacity by group and season

\begin{tabular}{|c|c|c|c|c|c|c|c|c|}
\hline \multirow{2}{*}{ Variables } & \multirow{2}{*}{ Level } & \multicolumn{3}{|c|}{ Season 2012/2013 } & \multicolumn{3}{|c|}{ Season $2013 / 2014$} & \multirow[b]{2}{*}{$p$} \\
\hline & & Mean & \pm & SD & Mean & \pm & SD & \\
\hline \multirow{2}{*}{$\begin{array}{c}\text { Time to peak } \\
\text { power (s) }\end{array}$} & Experimental & 2.79 & \pm & 0.60 & 2.79 & \pm & 0.46 & 0.79 \\
\hline & Control & 2.77 & \pm & 0.66 & 2.77 & \pm & 0.66 & 0.64 \\
\hline \multirow{2}{*}{$\begin{array}{l}\text { Relative Mean } \\
\text { Power }\left(\mathrm{W} \cdot \mathrm{kg}^{-1}\right)\end{array}$} & Experimental & 9.91 & \pm & 0.81 & 9.14 & \pm & 0.92 & 0.04 \\
\hline & Control & 9.94 & \pm & 0.85 & 10.04 & \pm & 0.88 & 0.76 \\
\hline \multirow{2}{*}{$\begin{array}{c}\text { Relative Peak } \\
\text { Power }\left(\mathrm{W} \cdot \mathrm{kg}^{-1}\right)\end{array}$} & Experimental & 20.87 & \pm & 1.92 & 20.01 & \pm & 1.43 & 0.21 \\
\hline & Control & 20.59 & \pm & 3.03 & 20.91 & \pm & 2.16 & 0.83 \\
\hline \multirow{2}{*}{$\begin{array}{l}\text { Relative Total } \\
\text { Work }\left(\mathrm{J} \cdot \mathrm{kg}^{-1}\right)\end{array}$} & Experimental & 299.17 & \pm & 15.78 & 277.22 & \pm & 26.37 & 0.04 \\
\hline & Control & 298.21 & \pm & 22.14 & 302.79 & \pm & 21.25 & 0.69 \\
\hline
\end{tabular}

Table 3

Basic statistical characteristics of the players' aerobic capacity by group and season

\begin{tabular}{|c|c|c|c|c|c|c|c|c|}
\hline \multirow{2}{*}{ Variables } & \multirow{2}{*}{ Level } & \multicolumn{3}{|c|}{ Season $2012 / 2013$} & \multicolumn{3}{|c|}{ Season $2013 / 2014$} & \multirow{2}{*}{$p$} \\
\hline & & Mean & \pm & SD & Mean & \pm & $\mathrm{SD}$ & \\
\hline \multirow{2}{*}{ Maximum power $(W)$} & Experimental & 384.60 & \pm & 16.47 & 364.10 & \pm & 21.96 & 0.034 \\
\hline & Control & 387.21 & \pm & 21.25 & 390.64 & \pm & 20.12 & 0.89 \\
\hline \multirow[t]{2}{*}{ RelativeVO2max $\left(\mathrm{ml} \cdot \mathrm{min}^{-1} \cdot \mathrm{kg}^{-1}\right)$} & Experimental & 52.70 & \pm & 3.13 & 48.30 & \pm & 3.20 & 0.009 \\
\hline & Control & 52.57 & \pm & 2.41 & 53.64 & \pm & 4.81 & 0.71 \\
\hline \multirow[t]{2}{*}{ LArest $\left(\mathrm{mmol} \cdot 1^{-1}\right)$} & Experimental & 1.17 & \pm & 0.23 & 1.24 & \pm & 0.41 & 0.90 \\
\hline & Control & 1.27 & \pm & 0.56 & 1.33 & \pm & 0.50 & 0.76 \\
\hline \multirow[t]{2}{*}{$\mathrm{LA}_{\max }\left(\mathrm{mmol} \cdot \mathrm{l}^{-1}\right)$} & Experimental & 11.62 & \pm & 1.13 & 10.91 & \pm & 2.01 & 0.42 \\
\hline & Control & 11.40 & \pm & 1.79 & 10.73 & \pm & 2.59 & 0.52 \\
\hline \multirow[t]{2}{*}{$\Delta \mathrm{LA}_{\max -3^{\prime}}\left(\mathrm{mmol} \cdot \mathrm{l}^{-1}\right)$} & Experimental & -0.17 & \pm & 1.04 & -1.34 & \pm & 1.18 & 0.026 \\
\hline & Control & -0.11 & \pm & 1.30 & -0.67 & \pm & 1.38 & 0.50 \\
\hline \multirow[t]{2}{*}{$\Delta \mathrm{LAmax}_{-6^{\prime}}\left(\mathrm{mmol} \cdot \mathrm{l}^{-1}\right)$} & Experimental & 0.80 & \pm & 1.36 & -1.15 & \pm & 1.23 & 0.005 \\
\hline & Control & 0.52 & \pm & 1.60 & 0.30 & \pm & 1.68 & 0.76 \\
\hline \multirow[t]{2}{*}{$\Delta \mathrm{LA}_{\max -9^{\prime}}\left(\mathrm{mmol} \cdot \mathrm{l}^{-1}\right)$} & Experimental & 1.86 & \pm & 1.27 & -0.35 & \pm & 1.35 & 0.001 \\
\hline & Control & 1.39 & \pm & 1.78 & 1.17 & \pm & 1.77 & 0.94 \\
\hline \multirow[t]{2}{*}{$\Delta \mathrm{LA}_{\max -12^{\prime}}\left(\mathrm{mmol} \cdot \mathrm{l}^{-1}\right)$} & Experimental & 3.37 & \pm & 1.12 & 0.71 & \pm & 1.42 & 0.0004 \\
\hline & Control & 2.61 & \pm & 1.89 & 2.26 & \pm & 1.75 & 0.58 \\
\hline
\end{tabular}




\begin{tabular}{|c|c|c|c|c|c|c|c|}
\hline \multicolumn{8}{|c|}{$\begin{array}{c}\text { Table } 4 \\
\text { Basic statistical characteristics of the players' performance during on-ice tests by group and season }\end{array}$} \\
\hline \multirow{2}{*}{ Variables } & \multirow{2}{*}{ Level } & \multicolumn{3}{|c|}{ Season $2012 / 2013$} & \multicolumn{2}{|c|}{ Season $2013 / 2014$} & \multirow{2}{*}{$p$} \\
\hline & & Mean & \pm & SD & Mean & $\pm \mathrm{SD}$ & \\
\hline \multirow[b]{2}{*}{30 m Sprint Forwards (s) } & Experimental & 4.38 & \pm & 0.17 & 4.42 & \pm 0.21 & 0.99 \\
\hline & Control & 4.24 & \pm & 0.14 & 4.23 & \pm 0.10 & 0.98 \\
\hline \multirow[t]{2}{*}{30 m Sprint Backwards (s) } & Experimental & 5.50 & \pm & 0.79 & 5.57 & \pm 0.87 & 0.92 \\
\hline & Control & 5.29 & \pm & 0.29 & 5.29 & \pm 0.29 & 0.96 \\
\hline \multirow[t]{2}{*}{$6 \times 9$ Turns (s) } & Experimental & 12.16 & \pm & 0.79 & 12.15 & \pm 0.76 & 0.96 \\
\hline & Control & 12.65 & \pm & 0.45 & 12.62 & \pm 0.44 & 0.78 \\
\hline \multirow[t]{2}{*}{$6 \times 9$ Stops $(\mathrm{s})$} & Experimental & 12.75 & \pm & 0.65 & 12.81 & \pm 0.79 & 0.75 \\
\hline & Control & 12.82 & \pm & 0.47 & 12.79 & \pm 0.43 & 0.85 \\
\hline \multirow{2}{*}{$\begin{array}{l}\text { Endurance }(6 \times 30 \mathrm{~m} \text { stops }) \\
\text { (s) }\end{array}$} & Experimental & 32.18 & \pm & 1.05 & 33.10 & \pm 0.70 & 0.80 \\
\hline & Control & 31.97 & \pm & 0.81 & 31.81 & \pm 0.60 & 0.047 \\
\hline
\end{tabular}

Statistically significant differences with regard to aerobic capacity were also found only between the results of the experimental group. Ice hockey players from the experimental group in the 2013/2014 season had lower values of relative $\mathrm{VO}_{2 \max }$ (48.30) compared to the results of the 2012/2013 season (52.70 $\left.\mathrm{ml} \cdot \mathrm{min}^{-1} \cdot \mathrm{kg}^{-1} ; p=0.009\right)$ which they played at the top league. Analysis of the results of maximum power in the ramp test showed a statistically significant decrease in the maximum power after a year spent in the lower league ( $p=0.034$; Table 3 ). Further analysis focused on blood lactate concentration. No significant differences were observed in the results of LArest and LAmax either in the experimental or the control group $(p>0.05)$. Analysis of increases and decreases in the delta of blood lactate concentrate revealed that significant changes took place only in the experimental group. The rate of recovery in that group was significantly lower for all $\Delta \mathrm{LA}$ values $\left(\mathrm{mmol} \cdot \mathrm{I}^{-1} ; p<0.05\right)$. In the next step, the analysis focused on the results of on-ice tests (Table 4).

No significant differences between the mean values $(p>0.05)$ were noted for the following variables: $30 \mathrm{~m}$ Sprint Forwards (s), 30 m Sprint Backwards (s), $6 \times 9$ Turns (s), $6 \times 9$ stops (s). Ice hockey players from the experimental group in the 2013/2014 season had worse values of endurance ( $6 \times 30 \mathrm{~m}$ Stops) (33.10) compared to the results of the 2012/2013 season (32.18 s; $p=0.047$ ) which they played at the top league.

\section{Discussion}

Ice hockey as a professional game is metabolically unique. It is physically demanding and requires finely trained aerobic and anaerobic energy pathways. If appropriate training addressing these areas is not applied detraining may occur, i.e. the deterioration of different physiological variables in ice-hockey players. Typically, hockey players train over the calendar year in 3 or 4 phases. These phases usually include some type of taper in the immediate offseason and a pre-season combination of aerobic and resistance training which attempts to maintain fitness gained earlier (Quiney, 1990). Lack of optimal training in the pre-season may bring players' $\mathrm{VO}_{2 \max }$ down and consequently reduce their rates of post-exercise recovery, a key 
determinant of ice-hockey players' performance. Analysis of the results obtained in the course of the study showed that a season played in the first league (lower level) caused detraining in the players in the experimental group that reduced their power output in its final stages in the ramp test from 384.60 to $364.10 \mathrm{~W}(p=0.034)$ and $\mathrm{VO}_{2 \max }$ from 52.70 to $48.30 \mathrm{ml} \cdot \mathrm{min}^{-1} \cdot \mathrm{kg}^{-1}(p=0.009)$. Because of lower $\mathrm{VO}_{2 \max }$, the rate of post-exercise recovery $\Delta \mathrm{LA} \mathrm{mmol} \cdot \mathrm{1}^{-1}$ at the $3 \mathrm{rd}, 6 \mathrm{th}, 9$ th and $12^{\text {th }} \mathrm{min}$ after the ramp test decreased as well. The players' maximal power output reduction may have been caused by decreased buffering capacity after a season played in the first league where intensity of play is much lower. The researchers have found that the aerobic system may be of prime importance for recovery (Czuba et al., 2009; Thoden, 1991; Zając et al., 2010, 2014). There are many mechanisms that can explain these results. Most of all, high aerobic power increases the ability to recover from repeated bouts of anaerobic exercise and probably decreases lactate concentrations in response to higher LA utilization in slow twitch muscle fibers (Tesch and Wright, 1983; Tomlin and Wenger, 2001). In other studies, a significant correlation between capillary density and blood lactate concentration was found, suggesting that an improved efflux of lactate resulted from increased capillary density (Tesch and Wright, 1983). Increased capillary density, as seen in endurance-trained individuals, provides a decreased diffusion distance between capillaries and muscle fibers, enhancing movement of oxygen and nutrients to, and the removal of $\mathrm{H}+$ and lactate from the muscle (Holloszy and Coyle, 1984). Harris et al. (1976) and Colliander et al. (1988) showed that enhanced oxygen delivery to muscles post-exercise potentially accelerated the rate of $\mathrm{PCr}$ resynthesis, an oxygen-dependent process. A different study allowed to identify a significant correlation between aerobic capacity measured with $\mathrm{VO}_{2 \max }$ and the fatigue index (FI) obtained during the $6 \mathrm{x}$ $89 \mathrm{~m}$ test (Stanula et al., 2014). The results of this study seem to indicate, therefore, that the recovery time and lactate clearance depend on the fitness level, the stage of training, active muscle mass, muscle fiber composition, nutritional status, the blood flow and fatigue (Basset et al., 1991; Cox et al., 1995; Koziris and Montgomery, 1991; Smith and Roberts, 1990). As a result of lower $\mathrm{VO}_{2 \max }$, the players in the experimental group may be less efficient in carrying out the tactical directions of their coaches during a game, because a lower rate of post-exercise recovery and oxygen debt building-up with successive shifts on ice will increase their fatigue. The study also showed that a season played in the first league had a significant and negative influence on the variables of the players' performance measured in the $30 \mathrm{~s}$ Wingate test: relative mean power declined from 9.91 to $9.14 \mathrm{~W} \cdot \mathrm{kg}^{-1}(p=0.04)$ and relative total work from 299.17 to $277.22 \mathrm{~J} \cdot \mathrm{kg}^{-1}(p=0.04)$. The players' performance in the on-ice $6 \times 30 \mathrm{~m}$ test was also significantly worse $(p=0.047)$. The relative peak power and time to peak power recorded in the experimental group in the $30 \mathrm{~s}$ Wingate test were not significantly worse. A season played in the first league did not have a negative effect on the results of activities determined by the ATP-PCr system (maximal effort - exercise duration up to 5 s), in contrast with the results of activities determined by $\mathrm{PCr}+$ glycogen $\left(\mathrm{O}_{2}\right)$ metabolic processes (maximal effort - exercise duration up to $30 \mathrm{~s}$ ). After a season in the first league, the players in the experimental group were found to have reduced glycolytic capacity. In the top league, a majority of game play is well below the LT (Cox et al., 1995; Stanula and Roczniok, 2014; Stanula et al., 2016). Ice-hockey players relegated to a lower (less demanding) league played at a considerably lower intensity. As a result, they had greater problems with coping with muscle acidification and their glycolytic capacity recorded during tests was lower. This allows to conclude that ice-hockey players who played a season in the first league and aspire to play again in the top league should have their training programs designed with the objective to improve their aerobic and glycolytic capacity. A useful tool seems to be high intensity interval training in normobaric hypoxia (IHT) as it has been demonstrated to be effective in increasing aerobic capacity and significantly improving post-exercise recovery. This has been confirmed in basketball players after 3 week of exposure to hypoxia (Czuba et al., 2013).

\section{Conclusion}

The study showed that playing a season in a lower ice-hockey league results in a significant decrease of physical fitness and performance. The 
maximal oxygen uptake of the players was reduced and the rates of post-exercise recovery after the ramp test were significantly lower. Variables of glycolytic capacity, i.e. relative mean power and relative total work in the $30 \mathrm{~s}$ Wingate test were also reduced. Furthermore, significant deterioration in the players' performance in the on-ice $6 \times 30 \mathrm{~m}$ test was noted. To make it possible for the talented ice-hockey players to continue their careers, they should optimize their preseason training, as observed in many top icehockey leagues in the world.

\section{References}

Basset DF, Merrill PN, Nagle FJ. Rate of decline in blood lactate after cycling exercise in endurance trained and untrained subjects. J Appl Physiol, 1991; 70: 1816-1820

Behm DG, Wahl MJ, Button DC, Power KE, Anderson KG. Relationship between hockey skating speed and selected performance measures. J Strength Cond Res, 2005; 19: 326-331.

Colliander EB, Dudley GA, Tesch PA. Skeletal muscle fiber type composition and performance during repeated bouts of maximal contractions. Eur J Appl Physiol, 1988; 58: 81-86

Cox MH, Miles DS, Verde TJ, Rhodes EC. Applied physiology of ice hockey. Sports Med, 1995; 19: 184-201

Czuba M, Zając A, Cholewa J, Poprzęcki S, Waśkiewicz Z, Mikołajec K. Lactate threshold (D-Max Method) and maximal lactate steady state in cyclists. J Hum Kinet, 2009; 21: 49-56

Czuba M, Zając A, Maszczyk A, Roczniok R, Poprzęcki S, Garbaciak W, Zając T. The effects of high intensity interval training in normobaric hypoxia on aerobic capacity in basketball players. J Hum Kinet, 2013; 39: 103-114

Green DJ, Maiorana A, O'Driscoll G, Taylor R. Effect of excercise training on endothlenium - derived nitric oxide function in humans. J Physiol, 2004; 561: 1-25

Harris RC, Edwards RHT, Hultman E, Nordesjö LO, Nylind B, Sahlin K. The time course of phosphocreatine resynthesis during recovery of the quadriceps muscle in man. Pflugers Arch, 1976; 367: 137-142

Holloszy JO, Coyle EF. Adaptations of skeletal muscle to endurance exercise and their metabolic consequences. J Appl Physiol, 1984; 56: 831-838

Koziris LP, Montgomery DL. Blood lactte concentration following intermittent and continuous cycling tests of anaerobic capacity. Eur J Appl Physiol, 1991; 63: 273-7

Lau S, Berg K, Latin RW, Noble J. Comparison of active and passive recovery of blood lactate and subsequent performance of repeated work bouts in ice hockey players. J Strength Cond Res, 2001; 5: 367-371

Magiera A, Roczniok R, Maszczyk A, Czuba M, Kantyka J, Kurek P. The structure of performance of a sport rock climber. J Hum Kinet, 2013; 36: 107-117

Montgomery DL. Physiological profile of professional hockey players - a longitudinal study. Appl Physiol Nutr Metab, 2006; 31: 181-185

Montgomery DL. Physiology of ice hockey. Sports Med, 1988; 5(2): 99-126

Quinney HA, Dewart R, Game A, Snydmiller G, Warburton D, Bell G. A 26 year physiological description of a National Hockey League team. Appl Physiol Nutr Metab, 2008; 33(4): 753-760

Quinney HA. Sport on ice. In: Reilly T, Secher R, Sevel P et al. editors. Physiology of sports, London: E and FW Sport, 311-36; 1990

Roczniok R, Maszczyk A, Stanula A, Czuba M, Pietraszewski P, Kantyka J, Starzyński M. Physiological and physical profiles and on-ice performance approach to predict talent in male youth ice hockey players during draft to hockey team. Isokinet Exerc Sci, 2013; 21(2): 121-127

Roczniok R, Stanula A, Maszczyk A, Mostowik A, Kowalczyk M, Fidos-Czuba O, Zając A. Physiological, physical and on-ice performance criteria for selection of elite ice hockey teams. Biol Sport, 2016; 33:43-8 
Smith DJ, Roberts D. Heart rate and blood lactate concentration during on-ice training in speed skating. Can J Sports Sci, 1990; 15: 23-27

Stanula A, Gabryś T, Roczniok R, Szmatlan-Gabryś U, Ozimek M, Mostowik A. Quantification of the demands during an ice-hockey game based on intensity zones determined from the incremental test outcomes J Strength Cond Res, 2016; 30(1): 176-183

Stanula A, Roczniok R, Maszczyk A, Pietraszewski P, Zając A. The role of aerobic capacity in high-intensity intermittent efforts in ice-hockey. Biol Sport, 2014; 31: 193-199

Stanula A, Roczniok R. Game intensity analysis of elite adolescent ice hockey players. J Hum Kinet, 2014; 44: 211-221

Stanula A, Gabryś T, Szmatlan-Gabryś U, Roczniok R, Maszczyk A, Pietraszewski P. Calculating lactate anaerobic thresholds in sports involving different endurance preparation. J Exerc Sci Fit, 2012; 11: 1218

Tesch P, Wright JE. Recovery from short term intense exercise; its relation to capillary supply and blood lactate concentration. Eur J Appl Physiol, 1983; 52: 98-103

Thoden JS. Testing aerobic power. In: MacDougall JD, Wenger HA, Green HJ, editors. Physiological testing of the high-performance athlete. Champaign (IL): Human Kinetics, 107-174; 1991

Tomlin DL, Wenger HA. The relationship between aerobic fitness and recovery from high intensity intermittent exercise. Sports Med, 2001; 31(1): 1-11

Zając A, Poprzęcki S, Maszczyk A, Czuba M, Michalczyk M, Zydek G. The Effects of a Ketogenic Diet on Exercise Metabolism and Physical Performance in Off-Road Cyclists. Nutrients, 2014; 6(7): 2493-2508

Zając A, Czuba M, Poprzecki S, Waśkiewicz Z, Cholewa J, Pilch J, Chycki J. Effects of growth hormone therapy and physical exercise on anaerobic and aerobic power, body composition, lipoprotein profile in middle aged men. J Hum Kinet, 2010; 25: 67-76

\section{Corresponding author:}

\section{Robert Roczniok}

Department of Sports Training, The Jerzy Kukuczka Academy of Physical Education, Katowice, Poland;

Address: Mikolowska Str.72A,

40-065, Katowice.

Phone: +48533487601

E-mail: r.roczniok@awf.katowice.pl 